\title{
Demografik Özellikler Açısından Tüketicilerin Plansız Satın Alma Davranış Farklılıklarını İncelemeye Yönelik Bir Araştırma
}

\author{
DOI: 10.26466/opus.596873
}

\begin{abstract}
Gamze Akçay*- Erkan Özdemir**
* Doktora Öğrencisi, Bursa Uludağ Üniversitesi, Sosyal Bilimler Enstitüsü, Nilüfer/Bursa/Türkiye E-Posta: gamzeakcay@hotmail.com ORCID: $0000-0001-6808-8465$

** Doç. Dr., Bursa Uludağ Üniversitesi, İktisadi ve İdari Bilimler Fakültesi, Nilüfer/Bursa/Türkiye E-Posta: eozdemir@uludag.edu.tr ORCID: 0000-0003-0903-7638
\end{abstract}

$\ddot{O} z$

Pazarlama literatüründe, plansız satın alma davranışı 1950'li yıllardan beri araştırılmaktadır. Bu çalışmalarda, tüketicilerin plansız satın alma davranışının demografik özelliklere göre farklılık gösterip göstermediği sıklıkla araştırılmıştır. Ancak, özellikle Türkiye'de tüketicilerin plansız satın alma davranışını cinsiyet, medeni durum, yaş, eğitim durumu ve gelir gibi demografik özelliklerin tümü açısından araştıran çalışmalar oldukça kısıtlıdır. Bu çalışmanın amacı, cinsiyet, medeni durum, yaş, eğitim durumu ve gelir gibi demografik özelliklere göre tüketicilerin plansız satın alma davranışının farklılık gösterip göstermediğini belirlemektir. Araştırma verileri Bursa'daki tüketicilerden yüz yüze anket yöntemiyle toplanmıştır. Elde edilen veriler, t-testi ve Varyans Analizi (ANOVA) kullanılarak analiz edilmiştir. Analiz sonucunda, tüketicilerin plansız satın alma davranışının cinsiyet ve yaşa göre anlaml farklllı gösterdiği, ancak medeni durum, eğitim durumu ve gelire göre anlaml farklhlı göstermediği bulunmuştur. Bu bulguya göre, kadın tüketiciler erkek tüketicilere göre daha fazla plansız satın alma davranışı gösterirken, 51 ve üzeri yaş grubunda olan tüketiciler diğer tüketicilere göre daha az plansız satın alma davranışı göstermektedirler.

Anahtar Kelimeler: Plansız Satın Alma Davranışı, Demografik Özellikler, ANOVA, $t$-Testi. 


\title{
Research to Examine Differences in Consumers' Impulse Buying Behavior in terms of Demographic Characteristics
}

\begin{abstract}
In the marketing literature, impulse buying behavior has been investigated since the 1950s. In these studies, it was frequently investigated whether the consumers' impulse buying behavior differed according to demographic characteristics. However, especially in Turkey, studies investigating consumers' impulse buying behavior in terms of all demographic characteristics such as gender, marital status, age, education status, and income are quite limited. The aim of this study is to determine whether consumers' impulse buying behavior differs according to demographic characteristics such as gender, marital status, age, education status, and income. Research data were collected from consumers in Bursa by a face-to-face survey. The data were analyzed by t-test and ANOVA. The results of the analysis, it was found that consumers' impulse buying behavior shows significant differences according to gender and age, however, no significant difference according to marital status, education status, and income. According to this finding, female consumers exhibit more impulse buying behavior than male consumers and consumers of 51 and overages exhibit less impulse buying behavior than other consumers.
\end{abstract}

Keywords: Impulse Buying Behavior, Demographic Characteristics, ANOVA, t-Test. 


\section{Giriş}

Plansız satın alma davranışı, pazarlama yazınında sıklıkla araştırılan konulardan biridir. Konuyla ilgili ilk araştırmalarda, tüketicilerin alışverişe çıktıktan veya mağazaya girdikten sonra verdikleri satın alma kararlarına odaklanılmıştır. Bu yaklaşıma göre plansız satın alma, tüketicilerin alışveriş listesinde yer almayan ürünlerin satın alımını içeren bir satın alma türü olarak değerlendirilmiştir (Clover, 1950; Stern; 1962). Sonraki yıllarda yapılan araştırmalarda ise kavramın kapsamı genişletilerek konunun psikolojik boyutlarına odaklanılmış ve tüketicilerin ruh halleri, duygusal durumları, kişisel özellikleri gibi içsel tetikleyicilere dayalı olarak plansız satın alma konusu araştırılmaya başlanmıştır (Rook, 1987; Rook ve Hoch, 1985).

Plansız satın alma kavramının literatüre kazandırılmasında önemli katkısı olan Stern (1962), plansız satın almayı, müşterinin alışveriş öncesi plan yapmaksızın gerçekleştirdiği tüm satın alımları kapsayan bir durum olarak dört alt kategori altında değerlendirmiştir. Bu alt kategoriler; tamamen plansız satın alma, hatırlatıcı plansız satın alma, öneriyle yapılan plansız satın alma ve planlanmış plansız satın almadır. Tamamen plansız satın alma, planlanmadan yapılan, normal satın alma davranışına aykırı bir satın almadır. Hatırlatıcı plansız satın alma, tüketicinin alışveriş sırasında gördüğü bir ürünle ilgili olarak, ürün stokunun bittiğini veya azaldığııı hatırlaması ya da ürüne ilişkin bir reklam veya bilginin daha önceden verilmiş bir satın alma kararını hatırlatması durumudur. Öneriyle yapılan plansız satın alma, tüketicinin ürünü gördüğ̈̈nde ürün hakkında daha önce bilgisi olmamasına rağmen, ürüne ihtiyacı olduğunu düşünerek gerçekleştirdiği satın alma durumudur. Planlanmış plansız satın alma ise tüketicinin mağazaya belirli ürünleri satın alma niyetiyle girmesi ancak özel fiyatlandırmalar, kupon teklifleri vb. etkisiyle farklı ürünler satın alması durumudur. Rook ve Hoch (1985) ise kavramı sadece "planlanmamış" bir satın alma türü olarak nitelendiren standart yaklaşımların aksine psikolojik bağlamda araştırmış ve plansız satın almayı beş unsuru içeren bir yapı olarak değerlendirmiştir. Bu bağlamda, plansız satın alma davranışı ani ve kendiliğinden duyulan bir arzuya dayalı olarak gerçekleşmekte, satın alma için duyulan ani dürtü tüketiciyi geçici olarak kontrol dışı bırakarak psikolojik bir dengesizlik yaratmakta, tüketici psikolojik bağlamda hem çatışmayı hem de mücadeleyi aynı anda yaşayabilmekte, tüketicinin ürünün özelliklerine yönelik bilişsel değerlendirmesi azalmakta ve satın almanın ortaya çıkaracağı sonuçlar göz 
ardı edilmektedir. Sonraki yıllarda yaptığı çalışmasında ise Rook (1987), satın alma sürecinde tüketicinin bir ürünü hemen satın almak için ani ve güçlü bir dürtü duyduğunu ve bu dürtünün plansız satın alma davranışı oluşturduğunu öne sürmüştür.

İlgili literatür incelendiğinde, tüketicilerin plansız satın alma davranışının demografik özelliklere göre farklılık gösterip göstermediğini araştıran ve farklı sonuçlara ulaşan çalışmaların (Ciunova-Shuleska, 2012; Gandhi, Vajpayee ve Gautam, 2015; Rana ve Tirthani, 2012; Yadav ve Mishra, 2017; Yang, Huang ve Feng, 2011) olduğu görülmektedir. Ancak, özellikle Türkiye' de tüketicilerin plansız satın alma davranışını cinsiyet, medeni durum, yaş, eğitim durumu ve gelir gibi demografik özelliklerin tümü açısından geniş bir örneklem grubu üzerinde araştıran çalışmaların sayısı (Kılıç, 2017; Özoğlu ve Bülbül, 2017) oldukça kısıtlıdır. Buradan hareketle bu çalışma, tüketicilerin plansız satın alma davranışının cinsiyet, medeni durum, yaş, eğitim durumu ve gelire göre farklılık gösterip göstermediğini geniş bir örneklem grubu üzerinde ortaya koymayı amaçlamaktadır. Bu açıdan, çalışmanın literatüre önemli katkı sağlayacağı düşünülmektedir.

Çalışma kapsamında, öncelikle plansız satın alma davranışına ilişkin bilgi verilmiş, literatür taraması yapılarak tüketicilerin demografik özellikleri açısından plansız satın alma davranışını araştıran çalışmalar incelenmiştir. Daha sonra, araştırma yöntemi ve analizler sonucu elde edilen bulgulara yer verilmiştir. Sonuç bölümünde ise araştırma sonuçları yorumlanarak, çalışmanın teorik ve pratiğe yönelik katkıları değerlendirilmiştir.

\section{Plansız Satın Alma Davranışı}

İngilizce "Impulse Buying" olarak ifade edilen kavram Türkçe'ye, "Plansız Satın Alma", "Ittkisel Satın Alma", "Dürtüsel Satın Alma", "Anlık Satın Al$m a "$ gibi farklı şekillerde çevrilmiştir. Bu çalışmada ise ilgili kavram "Plansız Satın Alma" şeklinde kullanılmıştır.

İlgili literatürde, plansız satın alma davranışıyla ilgili ilk araştırmalar kavramın tanımlanması ve açılanması üzerine odaklanmıştır (Rook, 1987; Rook ve Hoch; 1985; Stern, 1962). Sonraki yıllarda yapılan araştırmalarda ise plansız satın almayı etkileyen faktörlerin tespit edilmesi amaçlanmıştır. İlgili faktörlere göre plansız satın alma davranışı araştırmacılar tarafından farklı şekilde sinıflandırılmıştır. Bu çalışmada ise plansız satın alma davranışı üzerinde etkili olan faktörler; "dışsal tetikle- 
yiciler" (Mohan, Sivakumaran ve Sharma, 2013; Rasheed, Yaqup ve Baig, 2017; Tinne, 2011), "içsel tetikleyiciler" (Rook ve Gardner, 1993; Beatty ve Ferrell, 1998), "tüketicilere ilişkin durumsal faktörler" (Virvilaite, Saladiene ve Bagdonaite, 2009; Husnain, Rehman, Syed ve Akhtar, 2019) ve "tüketicilerin demografik özellikleri" (Awan ve Abbas, 2015; Ekeng, Lifu ve Asinya, 2012) şeklinde sınıflandırılmıştır.

Literatürde mağaza ortamı, ürün özellikleri, tanıtım faaliyetleri, mağaza personeli gibi dışsal tetikleyicilerin plansız satın alma davranışı üzerindeki etkisini araştıran pek çok çalışma bulunmaktadır. İlgili çalışmaların birinde Virvilaite vd. (2009), ürünün ve mağaza ortamı özelliklerinin tüketicilerin plansız satın alma davranışı üzerinde etkili olduğunu bulmuşlardır. Tinne (2011) ise tüketicilerin plansız satın alma davranışı üzerinde, fiyat stratejileri (ürünün fiyatı vb.), mağaza ortamı (ürünün sergilenmesi, satış personelinin davranışları vb.), tanıtım faaliyetleri (belirli marka sunumu, reklamlar vb.) gibi unsurların etkili olduğunu bulmuştur. Graa ve Dani-elKebir (2012) ise araştırmalarında mağaza ortamı ve mağazadaki algılanan kalabalıklığın plansız satın alma davranışını olumlu yönde etkilediğini bulmuşlardır. Giyim ve ayakkabı mağazalarında, tüketicilerin plansız satın alma davranışını etkileyen görsel mağazacılık unsurlarını araştıran Gudonaviciene ve Alijosiene (2015) ise araştırmaları sonucunda giyim mağazalarında, tüketicilerin plansız satın alma davranışını en fazla etkileyen görsel mağazacılık unsurlarının vitrin düzenlemesi ve mağaza içi tasarım olduğunu bulmuşlardır. Rasheed vd. (2017) ise alışveriş merkezlerindeki mağaza atmosferi, ödeme kolaylığı, satın alma noktasının görünümü ve tanıtım faaliyetlerinin plansız satın alma davranışı üzerinde etkili olduğu sonucuna ulaşmışlardır. Husnain vd. (2019) ise küçük şehirlerde yaşayan Y kuşağı tüketicileri üzerinde yaptıkları araştırmalarında mağaza ortamı, satış promosyonları ve mağaza personelinin müşterilere karşı dostça yaklaşımı gibi mağaza içi faktörlerin tüketicilerinin plansız satın alma davranışları üzerinde etkili olduğunu bulmuşlardır.

Plansız satın alma çalışmalarının bir kısmında, tüketicilerin ruh halleri, duygusal durumları ve hedonizm gibi içsel tetikleyicilerin plansız satın alma davranışı üzerindeki etkileri araştırılmıştır. Örneğin tüketicilerin ruh halinin plansız satın alma davranışı üzerindeki etkisini araştıran Rook ve Gardner (1993) araştırmaları sonucunda, tüketicilerin ruh halinin plansız satın alma davranışı üzerinde etkili olduğunu ve olumlu ruh haline sahip tüketicilerin olumsuz ruh haline sahip tüketicilere göre plansız satın alma davranışına daha yatkın olduklarını bulmuşlardır. 
Benzer bir araştırmada ise Beatty ve Ferrell (1998), olumlu ruh halinin tüketicilerde plansız satın alma dürtüsü yaratarak onları plansız satın alma davranışına yönelttiğini, ancak olumsuz ruh halinin bu tür bir etkisinin olmadığını bulmuşlardır. Plansız satın alma davranışı üzerinde tüketicilerin duygusal durumlarının etkisini araştıran Graa ve DanielKebir (2012) de araştırmaları sonucunda, tüketicilerin haz ve uyarılma duygularının plansız satın alma davranışı üzerinde olumlu, baskınlık duygusunun ise olumsuz yönde etkili olduğunu bulmuşlardır.

Hedonik alışveriş değeri ile plansız satın alma niyeti arasındaki ilişkiyi araştıran Yu ve Bastin (2010) araştırmaları sonucunda, hedonik alışveriş değeri ile plansız satın alma niyeti arasında olumlu bir ilişki olduğunu ve hedonik tecrübelerin daha fazla plansız satın alma yaratabileceğini bulmuşlardır. Hedonik tüketim ve plansız satın alma davranışı arasındaki ilişkiyi üç farklı etnik köken üzerinde araştıran Gunawan (2016) araştırma sonucunda, hedonik tüketim ve plansız satın alma davranışı arasında olumlu bir ilişki bulmuştur. Hedonik tüketim eğilimi ile faydacı tüketim eğiliminin plansız satın alma davranışı üzerindeki etkisini araştıran Türk (2018) araştırması sonucunda, her iki tüketim eğilimi türünün de plansız satın alma davranışı üzerinde olumlu etkiye sahip olduğunu ve hedonik tüketimin müşterileri faydacı tüketimden daha fazla plansız satın alma davranışına yönelttiğini bulmuştur.

Plansız satın alma çalışmalarının bazıları zaman ve para mevcudiyeti, aile, arkadaş vb. grupların etkisi gibi tüketicilere ilişkin durumsal faktörlerin plansız satın alma davranışı üzerindeki etkisiyle ilgilidir. Örneğin Beatty ve Ferrell (1998), tüketicilerin alışveriş esnasında sahip oldukları zaman ve paranın, tüketicilerin mağazada gezinme süresini ve ruh hallerini etkilediğini bulmuştur. Yeterli zaman ve para, tüketicilerin mağazada gezinme sürelerini arttırıp, ruh hallerini olumlu yönde etkilemekte, dolayısıyla plansız satın alma davranışı üzerinde olumlu bir etki yaratmaktadır. Plansız satın alma davranışına ilişkin teorik bir model önerisinde bulunan Virvilaite vd. (2009), alı̧̧veriş esnasında tüketicilerin sahip oldukları zamanın ve tüketiciler üzerinde etkisi olan aile, arkadaş gibi grupların plansız satın almayı etkilediğini öne sürmüşlerdir. Benzer bir araştırmada Graa ve Dani-elKebir (2012), müşteriler üzerindeki zaman baskısının plansız satın alma davranışını olumsuz yönde etkilediğini bulmuştur. Husnain vd. (2019) ise küçük şehirlerde yaşayan Y kuşağ1 tüketicileri üzerinde yaptıkları araştırmaları sonucunda, tüketicilerin plansız satın alma davranışları üzerinde mevcut zaman ve aile etkisinin 
olumlu yönde, mevcut paranın ise olumsuz yönde etkili olduğunu bulmuştur.

Literatürde plansız satın alma davranışı üzerindeki etkisi araştırılan bir diğer faktör, tüketicilerin demografik özellikleridir. Tüketicilerin demografik özellikleri açısından plansız satın alma davranışının farklılık gösterip göstermediğinin belirlenmesi bu çalışmanın amacını oluşturmaktadır. Dolayısıyla ilgili konuya ilişkin literatür incelemesi ayrı bir başlık altında detaylı olarak aşağıda ele alınmıştır.

\section{Demografik Özellikler Açısından Tüketicilerin Plansız Satın Alma Davranışı}

Pazarlama literatüründe, demografik özellikler ile tüketicilerin plansız satın alma davranışı arasındaki ilişkiyi konu alan çalışmalar bulunmaktadır. Bu çalışmaların bir kısmı, demografik özellikler açısından tüketicilerin plansız satın alma davranışının farklılık gösterip göstermediğini araştırırken, bir kısmı ise demografik özelliklerin tüketicilerin plansız satın alma davranışı üzerindeki etkisini ortaya koymayı amaçlamaktadır.

Demografik özellikler açısından tüketicilerin plansız satın alma davranışının farklılık gösterip göstermediğini araştıran çalışmalardan birinde Yang vd. (2011), kadın tüketicilerin kozmetik ürünlerine yönelik plansız satın alma niyetinin yaş grubuna göre farklılık gösterdiğini ve 40 yaş üzerindeki kadınların plansız satın alma yapma olasılığının daha yüksek olduğunu bulmuşlardır. Kadın tüketicilerin medeni durumu, eğitim durumu, mesleği ve geliri açısından ise kozmetik ürünlerine yönelik plansız satın alma niyeti farklılık göstermemektedir. Ancak, düşük gelirli kadın tüketiciler ile kadın üniversite öğrencileri kozmetik ürünlerindeki promosyonlardan daha fazla etkilenerek plansız satın alma yapabilmektedirler. Ciunova-Shuleska (2012) tarafından yapılan bir çalışmada, plansız satın alma davranışının tüketicilerin yaş grubu ve gelir düzeyine göre farklılık gösterdiği, genç ve yüksek gelirli tüketicilerin daha fazla plansız satın alma yaptığı bulunmuştur. Bu çalışmada, plansız satın alma davranışının tüketicilerin cinsiyeti, eğitim durumu ve çalışma durumuna göre ise farklılık göstermediği bulunan bir diğer sonuçtur. Hazır giyim ürünleri açısından tüketicilerin plansız satın alma davranışını araştıran Rana ve Tirthani (2012), eğitim durumu ve gelir açısından plansız satın alma davranışının farklılık gösterdiğini bulmuşlardır. Bu çalışmanın sonuçlarına göre, eğitim düzeyi yüksek tüketiciler daha az, gelir düzeyi yüksek tüketiciler ise daha fazla plansız satın alma yapmak- 
tadırlar. Cinsiyet açısından ise plansız satın alma davranışında bir farklılık bulunmamıştır. Awan ve Abbas (2015), cinsiyet, yaş, eğitim durumu ve gelire göre plansız satın alma davranışının farklılık gösterdiğini bulmuşlardır. Buna göre, erkekler kadınlara göre, genç tüketiciler yaşlı tüketicilere göre, yüksek gelirli tüketiciler düşük gelirli olanlara göre ve eğitim düzeyi yüksek tüketiciler eğitim düzeyi düşük olanlara göre daha fazla plansız satın alma yapmaktadırlar. İçecek ürünlerine yönelik plansız satın alma davranışının tüketicilerin demografik özellikleri açısından farklılaşma durumunu araştıran Gandhi vd. (2015), cinsiyet ve yaşa göre içecek ürünlerine yönelik plansız satın alma davranışının farklılaştığını bulmuşlardır. Elde edilen sonuçlara göre, kadın tüketiciler ile 30-40 yaş arası tüketiciler en fazla plansız satın alma yapan tüketici grubunu oluşturmaktadır. Öz ve Mucuk (2015) çalışmalarında, plansız satın alma davranışının cinsiyet, medeni durum ve gelire göre farklılık gösterdiğini bulmuşlardır. Araştırma sonuçları, erkek tüketicilerin kadın tüketicilere göre ve evli tüketicilerin bekâr tüketicilere göre daha fazla plansız satın alma yaptıklarını ve $4001 \mathrm{TL}$ ve üzeri aylık geliri olan tüketicilerin diğer tüketicilere göre daha az plansız satın alma yaptıklarını göstermektedir. Özgüven Tayfun (2015) çalışmalarında, plansız satın alma davranışının cinsiyet, eğitim durumu ve mesleğe göre farklılık gösterdiğini, yaş ve gelire göre ise farklılık göstermediğini bulmuştur. Buna göre kadınlar, ev hanımları ve eğitim düzeyi düşük tüketiciler diğerlerine göre daha fazla plansız satın alma davranışı göstermektedirler. Harwani ve Kanade (2017) tarafından yapılan çalışmada, cinsiyet, yaş, gelir ve meslek grubuna göre plansız satın alma davranışının farklılık gösterdiği bulunmuştur. Bu çalışmanın sonuçlarına göre, kadınlar erkeklere göre daha fazla plansız satın alma yapmakta ve yaş grubu açısından en fazla plansız satın almayı 25-35 yaş arası tüketiciler yapmaktadırlar. Tüketicilerin gelirleri yükseldikçe plansız satın alma davranışı artmaktadır. Son olarak bu çalişmada, en fazla plansız satın alma yapan meslek grubunun ise hizmet sektörü çalışanları olduğu bulunmuştur. Kılıç (2017) ise mağaza atmosferi, arkadaş, duygusal durum ve promosyon boyutlarından oluşan plansız satın alma davranışının, gelir ve eğitim durumuna göre farklılık göstermediğini, cinsiyet, medeni durum ve yaşa göre ise kısmen farklılık gösterdiğini bulmuştur. Buna göre, kadın tüketiciler promosyon ve duygusal durum faktörlerine, bekâr tüketiciler arkadaş ve duygusal durum faktörlerine, genç tüketiciler ise arkadaş faktörüne daha duyarlıdırlar.

Giyim ve teknoloji ürünlerine yönelik plansız satın alma eğiliminin tüketicilerin demografik özellikleri açısından farklılık gösterip göster- 
mediğini araştıran Özoğlu ve Bülbül (2017) araştırmaları sonucunda, teknoloji ürünlerine yönelik plansız satın alma eğiliminin cinsiyet, medeni durum, gelir ve eğitim düzeyine göre farklılık gösterdiğini, yaşa göre ise farklılık göstermediğini bulmuşlardır. Buna göre, erkek ve bekâr tüketiciler, kadın ve evli tüketicilere göre teknoloji ürünlerine yönelik daha fazla plansız satın alma eğilimi göstermektedirler. Ayrıca, tüketicilerin gelir ve eğitim düzeyi yükseldikçe teknoloji ürünlerine yönelik plansız satın alma eğilimi de azalmaktadır. Giyim ürünlerine yönelik plansız satın alma eğilimi ise cinsiyet, medeni durum, gelir ve yaşa göre farklılık göstermezken, eğitim durumuna göre farklılık göstermektedir. Tüketicilerin eğitim düzeyi yükseldikçe giyim ürünlerine yönelik plansız satın alma eğilimi azalmaktadır. Plansız satın alma davranışının demografik özellikler açısından farklılaşma durumunu perakende sektörü tüketicileri üzerinde araştıran Yadav ve Mishra (2017) ise araştırmaları sonucunda, eğitim ve meslek durumuna göre plansız satın alma davranışının farklılık gösterdiğini bulmuşlardır. Buna göre, eğitim düzeyi düşük olan tüketiciler diğerlerine göre daha fazla plansız satın alma yapmaktadırlar. Plansız satın alma davranışının en fazla olduğu meslek grubunu ise öğrenciler oluşturmaktadır. Cinsiyet, medeni durum ve yaş açısından ise plansız satın alma davranışında bir farklılık bulunmamıştır.

Tüketicilerin plansız satın alma davranışının demografik özellikler açısından farklılık gösterip göstermediğini araştıran çalışmaların yanı sıra literatürde, demografik özelliklerin tüketicilerin plansız satın alma davranışı üzerindeki etkisini ortaya koymaya yönelik yapılan çalışmalar da bulunmaktadır. Örneğin, demografik özelliklerin tüketicilerin plansız satın alma davranışı üzerindeki etkisini araştıran Ghani ve Jan (2011) araştırmaları sonucunda, cinsiyet ve gelirin plansız satın alma davranışı üzerinde etkili olmadığını, yaşın ise plansız satın alma davranışı üzerinde etkili olduğunu bulmuşlardır. Buna göre, genç tüketiciler yaşlı tüketicilere göre daha fazla plansız satın alma yapmaktadırlar. Ekeng vd. (2012) ise cinsiyet, yaş, gelir ve eğitim durumunun plansız satın alma davranışı üzerinde etkili olduğunu bulmuşlardır. Buna göre, kadınlar erkeklere göre, genç tüketiciler yetişkin tüketicilere göre, gelir düzeyi yüksek tüketiciler düşük olanlara göre ve eğitim düzeyi yüksek olan tüketiciler düşük olanlara göre daha fazla plansız satın alma yapmaktadırlar.

Cinsiyet, yaş, gelir ve eğitim durumundan oluşan demografik özelliklerin plansız satın alma davranışı üzerindeki çoklu etkisini araştıran Awan ve Abbas (2015), bu demografik özelliklerin plansız satın alma 
davranışı üzerinde olumlu yönde etkisi olduğunu bulmuşlardır. Y kuşağ1 tüketicilerinin demografik özelliklerinin moda giyim ürünlerine yönelik plansız satın alma davranışı üzerindeki etkisini araştıran Khan, Hui, Chen ve Hoe (2016), cinsiyetin Y kuşağı tüketicilerinin moda giyim ürünlerine yönelik plansız satın alma davranışı üzerinde etkili olduğunu bulmuşlardır. Buna göre, kadınlar erkeklere göre daha fazla plansız satın alma davranışında bulunmaktadırlar. Y kuşağı tüketicilerinin moda giyim ürünlerine yönelik plansız satın alma davranışı üzerinde gelir düzeyinin etkili olmadığı bulunmuştur. Sangalang, Siochi ve Plaza (2017) ise demografik özelliklerin tüketicilerin plansız satın alma davranışını etkilediğini bulmuşlardır. Buna göre, evli tüketiciler bekâr tüketicilere göre, yüksek gelirli tüketiciler düşük gelirli tüketicilere göre ve $42-49$ yaş aras1 tüketiciler diğerlerine göre daha fazla plansız satın alma yapmaktadırlar. Cinsiyet ve meslek durumunun ise plansız satın alma davranışı üzerinde herhangi bir etkisi bulunmamıştır.

Tüketicilerin plansız satın alma davranışının demografik özelliklere göre farklılık gösterip göstermediğini belirlemeye yönelik ilgili literatürde yer alan çalışmaların özeti aşağıdaki Tablo 1'de görülmektedir. 
Tablo 1. Tüketicilerin Plansız Satın Alma Davranışının Demografik Özelliklere Göre Farklılaşma Durumunu Araştıran Çalışmalar

\begin{tabular}{|c|c|c|c|c|c|c|c|c|c|}
\hline Yazar/lar & Sektör & $\begin{array}{l}\text { Hedef Kitle ve } \\
\text { Örneklem Hacmi }\end{array}$ & Cinsiyet & Yaş & $\begin{array}{l}\text { Medeni } \\
\text { Durum }\end{array}$ & Eğitim & Gelir & Meslek & Bulgular \\
\hline $\begin{array}{l}\text { Awan ve } \\
\text { Abbas (2015) }\end{array}$ & - & $-/ 250$ & Farkll1lk var. & $\begin{array}{l}\text { Farklilık } \\
\text { var. }\end{array}$ & - & $\begin{array}{l}\text { Farklılık } \\
\text { var. }\end{array}$ & $\begin{array}{l}\text { Farklılık } \\
\text { var. }\end{array}$ & - & $\begin{array}{l}\text { Erkek, genç, eğitim düzeyi ve gelir düzeyi yüksek tüketi- } \\
\text { ciler daha fazla plansız satın alma yapmaktadır. }\end{array}$ \\
\hline Yang vd. (2011) & Kozmetik & Kadın tüketiciler / 360 & - & $\begin{array}{l}\text { Farklilık } \\
\text { var }\end{array}$ & Farklılık yok & $\begin{array}{l}\text { Farklılık } \\
\text { yok }\end{array}$ & $\begin{array}{l}\text { Farklilik } \\
\text { yok }\end{array}$ & $\begin{array}{l}\text { Farklılık } \\
\text { yok }\end{array}$ & $\begin{array}{l}40 \text { yaş ve üzerindeki kadın tüketiciler daha fazla plansız } \\
\text { satın alma yapmaktadır. }\end{array}$ \\
\hline $\begin{array}{l}\text { Ciunova- } \\
\text { Shuleska (2012) }\end{array}$ & - & Market müşterileri / 195 & Farkl11ık yok & $\begin{array}{l}\text { Farkll11k } \\
\text { var. }\end{array}$ & - & $\begin{array}{l}\text { Farklilik } \\
\text { yok }\end{array}$ & $\begin{array}{l}\text { Farklilik } \\
\text { var }\end{array}$ & $\begin{array}{l}\text { Farklilik } \\
\text { yok }\end{array}$ & $\begin{array}{l}\text { Genç ve gelir düzeyi yüksek tüketiciler daha fazla plan- } \\
\text { ssz satın alma yapmaktadır. }\end{array}$ \\
\hline $\begin{array}{l}\text { Rana ve } \\
\text { Tirthani (2012) }\end{array}$ & $\begin{array}{l}\text { Hazır } \\
\text { Giyim }\end{array}$ & Hazır giyim tüketicileri / 450 & Farklıl1k yok & - & - & $\begin{array}{l}\text { Farklılık } \\
\text { var }\end{array}$ & $\begin{array}{l}\text { Farklilik } \\
\text { var }\end{array}$ & - & $\begin{array}{l}\text { Eğitim düzeyi yüksek tüketiciler daha az, gelir düzeyi } \\
\text { yüksek tüketiciler daha fazla plansız satın alma yapmak- } \\
\text { tadır. }\end{array}$ \\
\hline $\begin{array}{l}\text { Gandhi vd. } \\
\text { (2015) }\end{array}$ & İçecek & Mağaza müşterileri / 93 & Farklılık var & $\begin{array}{l}\text { Farklilık } \\
\text { var }\end{array}$ & - & - & - & - & $\begin{array}{l}\text { Kadın ve } 30-40 \text { yaş arasındaki tüketiciler daha fazla } \\
\text { plansız satın alma yapmaktadır. }\end{array}$ \\
\hline $\begin{array}{l}\text { Harwani ve } \\
\text { Kanade (2017) }\end{array}$ & - & 15 yaş üzeri tüketiciler / 130 & Farklılık var & $\begin{array}{l}\text { Farklılık } \\
\text { var }\end{array}$ & - & - & $\begin{array}{l}\text { Farklılık } \\
\text { var }\end{array}$ & $\begin{array}{l}\text { Farklılık } \\
\text { var }\end{array}$ & $\begin{array}{l}\text { Kadın, } 25-35 \text { yaş arasındaki, gelir düzeyi yüksek ve } \\
\text { hizmet sektöründe çalışan tüketiciler daha fazla plansız } \\
\text { satın alma yapmaktadır. }\end{array}$ \\
\hline $\begin{array}{l}\text { Öz ve } \\
\text { Mucuk (2015) }\end{array}$ & - & $-/ 625$ & Farklılik var & - & Farklılik var & - & $\begin{array}{l}\text { Farklılık } \\
\text { var }\end{array}$ & - & $\begin{array}{l}\text { Erkek ve evli tüketiciler daha fazla, } 4001 \text { TL ve üzeri } \\
\text { geliri olan tüketiciler daha az plansız satın alma yapmak- } \\
\text { tadır. }\end{array}$ \\
\hline $\begin{array}{l}\text { Özgüven } \\
\text { Tayfun (2015) }\end{array}$ & - & Market müşterileri / 384 & Farklılik var & $\begin{array}{l}\text { Farkll1lk } \\
\text { yok }\end{array}$ & - & $\begin{array}{l}\text { Farkl1l1k } \\
\text { var }\end{array}$ & $\begin{array}{l}\text { Farklılık } \\
\text { yok }\end{array}$ & $\begin{array}{l}\text { Farklılık } \\
\text { var }\end{array}$ & $\begin{array}{l}\text { Kadın, eğitim düzeyi düşük ve ev hanımı olan tüketiciler } \\
\text { daha fazla plansız satın alma yapmaktadır. }\end{array}$ \\
\hline Kılıç (2017) & - & $-/ 350$ & $\begin{array}{l}\text { Kismen } \\
\text { Farklilık var. }\end{array}$ & $\begin{array}{l}\text { Kismen } \\
\text { Farkll11k } \\
\text { var. }\end{array}$ & $\begin{array}{l}\text { Kismen } \\
\text { Farklilık var. }\end{array}$ & $\begin{array}{l}\text { Farklılık } \\
\text { yok. }\end{array}$ & $\begin{array}{l}\text { Farklılık } \\
\text { yok. }\end{array}$ & - & $\begin{array}{l}\text { Plansız satın alma açısından; kadın tüketiciler promos- } \\
\text { yon ve duygusal duruma, bekâr tüketiciler arkadaş ve } \\
\text { duygusal duruma, genç tüketiciler ise arkadaş faktörüne } \\
\text { daha duyarlıdır. }\end{array}$ \\
\hline \multirow{2}{*}{$\begin{array}{l}\text { Özoğlu ve } \\
\text { Bülbül (2017) }\end{array}$} & Teknoloji & \multirow{2}{*}{$-/ 870$} & Farklılik var. & $\begin{array}{l}\text { Farklilık } \\
\text { yok. }\end{array}$ & Farkll1ık var. & $\begin{array}{l}\text { Farkll11k } \\
\text { var. }\end{array}$ & $\begin{array}{l}\text { Farklılık } \\
\text { var. }\end{array}$ & & $\begin{array}{l}\text { Erkek, bekâr, eğitim ve gelir düzeyi düşük tüketiciler } \\
\text { daha fazla plansız satın alma yapmaktadır. }\end{array}$ \\
\hline & Giyim & & Farkllılı yok. & $\begin{array}{l}\text { Farkll1lk } \\
\text { yok. }\end{array}$ & Farklılık yok. & $\begin{array}{l}\text { Farkll11k } \\
\text { var. }\end{array}$ & $\begin{array}{l}\text { Farklilik } \\
\text { yok. }\end{array}$ & & $\begin{array}{l}\text { Ĕ̆itim düzeyi düşük tüketiciler daha fazla plansız satın } \\
\text { alma yapmaktadır. }\end{array}$ \\
\hline $\begin{array}{l}\text { Yadav ve } \\
\text { Mishra (2017) }\end{array}$ & - & Perakende tüketicileri / 100 & Farkllılk yok. & $\begin{array}{l}\text { Farklılık } \\
\text { yok. }\end{array}$ & Farklılık yok. & $\begin{array}{l}\text { Farklılık } \\
\text { var. }\end{array}$ & - & $\begin{array}{l}\text { Farklilık } \\
\text { var. }\end{array}$ & $\begin{array}{l}\text { Eğitim düzeyi düşük tüketiciler ve öğrenciler daha fazla } \\
\text { plansız satın alma yapmaktadır. }\end{array}$ \\
\hline
\end{tabular}


Yukarıdaki Tablo 1 incelendiğinde, ilgili çalışmaların tüketicilerin plansız satın alma davranışını cinsiyet, medeni durum, yaş, eğitim durumu, gelir ve meslek grubu gibi demografik özellikler açısından araştırdıkları ve farklı bulgulara ulaştıkları görülmektedir. Ancak, meslek grubu dışında ilgili demografik değişkenlerin tümü açısından tüketicilerin plansız satın alma davranışını geniş bir örneklem grubu üzerinde araştıran çalışmaların sayısı özellikle de Türkiye'de yok denecek kadar azdır. Dolayısıyla tüketicilerin plansız satın alma davranışının cinsiyet, medeni durum, yaş, eğitim durumu ve gelire göre farklılık gösterip göstermediğini, 437 katılımcıdan oluşan geniş bir örneklem grubu üzerinde araştıran bu çalışmanın literatüre önemli katkı sağlayacağı düşünülmektedir. Buradan yola çıkılarak, tüketicilerin plansız satın alma davranışının demografik özelliklere göre farklılık gösterip göstermediğini ortaya koymaya yönelik olarak aşağıdaki hipotezler geliştirilmiştir:

- H1: Tüketicilerin plansız satın alma davranışı cinsiyete göre anlamlı bir farklılık gösterir.

- $\quad \mathbf{H}_{2}$ : Tüketicilerin plansız satın alma davranışı medeni duruma göre anlamlı bir farklılık gösterir.

- $\mathbf{H}_{3}$ : Tüketicilerin plansız satın alma davranışı yaşa göre anlamlı bir farkl1lık gösterir.

- $\quad \mathbf{H}_{4}$ : Tüketicilerin plansız satın alma davranışı eğitim durumuna göre anlamlı bir farklılık gösterir.

- Hs: Tüketicilerin plansız satın alma davranışı gelire göre anlamlı bir farklılık gösterir.

\section{Yöntem}

Araştırmanın amacı, tüketicilerin plansız satın alma davranışının demografik özelliklere göre farklılık gösterip göstermediğini ortaya koymaktır. Bursa ilinde ikamet eden tüketiciler üzerinde gerçekleştirilen araştırmada, maliyet ve süre gibi kısıtlayıcı faktörler de göz önüne alınarak kolayda örnekleme yöntemi kullanılmıştır.

Araştırma verileri 01-31 Ağustos 2018 tarihleri arasında, Bursa ili Nilüfer ilçesinde yer alan iki büyük alışveriş merkezine gelen müşterilerle yüz yüze anket yöntemi kullanılarak toplanmıştır. Araştırma sonucunda 
analize uygun 437 ankete ulaşılmıştır. Elde edilen veriler, IBM SPSS 23 paket programı kullanılarak analiz edilmiştir.

Araştırmada kullanılan anket formu iki bölümden oluşmaktadır. İlk bölümde, katılımcların demografik özelliklerini belirlemeye yönelik beş adet kategorik soru yer almaktadır. Sonraki bölümde ise tüketicilerin plansız satın alma davranışını ölçmeye yönelik, Weun, Jones ve Beatty (1997) tarafından geliştirilen ve beş ifadeden oluşan 5'li Likert tipi ölçek soruları bulunmaktadır. Bu ölçeğin Türk kültürü açısından geçerlilik ve güvenirlilik analizleri Torlak ve Tiltay (2010) tarafından yapılmıştır. Bu nedenle, çalışmada bu ölçeğin kullanılmasının uygun olduğuna karar verilmiştir.

\section{Veri Analizleri ve Bulgular}

Araştırmada elde edilen veriler, araştırma hipotezlerinin test edilmesi amacıyla bağımsız örneklem t-testi ve tek yönlü varyans analizi (ANOVA) kullanılarak analiz edilmiştir. Bu aşamaya gelmeden önce, araştırma katılımcılarının demografik özelliklerine ilişkin sonuçlar frekans analiziyle ortaya konmuştur. Daha sonra araştırmada kullanılan plansız satın alma ölçeğinin güvenirlik analizi yapılmıştır. Sonrasında ise bağımsız örneklem t-testi ve tek yönlü varyans analizi (ANOVA) yapılarak, elde edilen sonuçlar değerlendirilmiştir.

\section{Frekans Analizi Sonuçları}

Araştırmaya katılan tüketicilerin demografik özelliklerine ilişkin veriler frekans analiziyle incelenmiştir. Tablo 2'de araştırmaya katılan katılımc1ların demografik verileri görülmektedir.

Tablo 2'de görüldüğü üzere, cevaplayıcıların çoğunluğunu erkek (\%57) ve 21-30 yaş arasındaki (\%52,2) tüketiciler oluşturmaktadır. Cevaplayıcıların medeni durumu incelendiğinde, evli olanların oranının $(\% 50,3)$ bekâr olanlarla $(\% 49,7)$ neredeyse aynı olduğu görülmektedir. Cevaplayıcıların eğitim durumu incelendiğinde, lisans (\%54), yüksek lisans $(\% 21,3)$, lise $(\% 20,4)$, doktora $(\% 3)$ ve ilköğretim $(\% 1,4)$ şeklinde sıralandığı görülmektedir. Araştırmanın Bursa Nilüfer ilçesinde yer alan alı̧̧veriş merkezlerine gelen müşteriler üzerinde yapılmış olması ve Bur- 
sa Uludağ Üniversitesinin de bu bölgede yer alması araştırma katılımc1ları içerisindeki lisans öğrencisi ve/veya lisans mezunu sayısının oldukça yüksek olmasının nedeni olarak ifade edilebilir. Elde edilen aylık gelir açısından ise cevaplayıcıların yarısından çoğunun $(\% 59,5)$ aylık geliri 2001 TL - 4000 TL arasindadir.

Tablo 2. Katılımcıların Demografik Özellikleri

\begin{tabular}{|c|c|c|c|}
\hline \multicolumn{2}{|c|}{ Demografik Özellikler } & $\mathbf{N}$ & $\%$ \\
\hline \multirow{2}{*}{ Cinsiyet } & Kadin & 188 & 43,0 \\
\hline & Erkek & 249 & 57,0 \\
\hline \multirow{5}{*}{ Yaş } & 20 yaş ve altı & 15 & 3,4 \\
\hline & $21-30$ yaş & 228 & 52,2 \\
\hline & $31-40$ yaş & 134 & 30,7 \\
\hline & $41-50$ yaş & 51 & 11,7 \\
\hline & 51 yaş ve üzeri & 9 & 2,1 \\
\hline \multirow{2}{*}{ Medeni Durum } & Bekâr & 217 & 49,7 \\
\hline & Evli & 220 & 50,3 \\
\hline \multirow{5}{*}{ Eğitim Durumu } & İlköğretim & 6 & 1,4 \\
\hline & Lise & 89 & 20,4 \\
\hline & Lisans & 236 & 54,0 \\
\hline & Yüksek Lisans & 93 & 21,3 \\
\hline & Doktora & 13 & 3,0 \\
\hline \multirow{5}{*}{ Gelir } & 2000 TL ve alt1 & 85 & 19,5 \\
\hline & 2001 TL-3000 TL & 124 & 28,4 \\
\hline & 3001 TL-4000 TL & 136 & 31,1 \\
\hline & 4001 TL-5000 TL & 72 & 16,5 \\
\hline & 5001 TL ve üzeri & 20 & 4,6 \\
\hline Toplam & & 437 & 100 \\
\hline
\end{tabular}

\section{Güvenirlik Analizi Sonuçları}

Araştırmada, plansız satın alma davranışını ölçmek için Weun vd. (1997) tarafından geliştirilen ve beş ifadeden oluşan ölçek kullanılmıştır. Ölçekteki ifadelerin güvenirlik analizi Cronbach's Alpha yöntemi kullanılarak yapılmıştır. Bu analiz sonucunda, ölçeğin güvenirliği (Cronbach's Alpha değeri) 0,912 bulunmuştur. Cronbach's Alpha değeri için genel olarak kabul edilen alt sinır 0,70'dir (Hair, Black, Babin ve Anderson, 2014, s.123). Dolayısıyla araştırmada kullanılan ölçeğin güvenilir olduğu ifade edilebilir. 


\section{Bă̆ımsız Örneklem t-Testi Sonuçları}

Plansız satın alma davranışının cinsiyet ve medeni duruma göre farklılık gösterip göstermediğini belirlemeye yönelik oluşturulan hipotezler bağımsız örneklem t-testi kullanılarak analiz edilmiştir. Aşağıdaki Tablo 3 'de cinsiyete göre bağımsız örneklem t-testi sonuçları görülmektedir.

Tablo 3. Cinsiyete Göre Bağımsız Örneklem t-Testi Sonuçları

\begin{tabular}{llllll}
\hline Cinsiyet & $\mathbf{N}$ & $\overline{\mathbf{X}}$ & ss. & $\mathbf{T}$ & $\mathbf{p}$ \\
\hline Kadın & 188 & 3,530 & 1,043 & 10,663 & 0,000 \\
Erkek & 249 & 2,461 & 1,034 & & \\
\hline
\end{tabular}

Yukarıdaki Tablo 3 incelendiğinde, $\mathrm{p}$ değerinin 0,05 'den küçük olduğu $(p=0,000<0,05)$ görülmektedir. Buna göre tüketicilerin plansız satın alma davranışı cinsiyete göre anlamlı bir farklılık göstermektedir. Dolayısıyla $\mathrm{H}_{1}$ hipotezi kabul edilmiştir. Plansız satın alma davranışının cinsiyete göre ortalama değerleri incelendiğinde, kadın tüketicilerin $(\overline{\mathrm{X}}=3,530)$, erkek tüketicilere $(\overline{\mathrm{X}}=2,461)$ göre daha fazla plansız satın alma davranışında bulundukları görülmektedir.

Aşağıdaki Tablo 4'de medeni duruma göre bağımsız örneklem t-testi sonuçları görülmektedir.

Tablo 4. Medeni Duruma Göre Bağımsız Örneklem t-Testi Sonuçları

\begin{tabular}{lcclll}
\hline Medeni Durum & $\mathbf{N}$ & $\overline{\mathbf{X}}$ & ss. & $\mathbf{T}$ & $\mathbf{p}$ \\
\hline Bekâr & 217 & 2,899 & 1,130 &,- 387 & 0,699 \\
Evli & 220 & 2,942 & 1,199 & & \\
\hline
\end{tabular}

Yukarıdaki Tablo 4 incelendiğinde, $\mathrm{p}$ değerinin $0,05^{\prime}$ den büyük olduğu $(p=0,699>0,05)$ görülmektedir. Buna göre, tüketicilerin plansız satın alma davranışı medeni duruma göre anlamlı bir farklılık göstermemektedir. Dolayısıyla $\mathrm{H}_{2}$ hipotezi reddedilmiştir.

\section{Tek Yönlï Varyans Analizi (ANOVA) Sonuçları}

Plansız satın alma davranışının yaş, eğitim durumu ve gelire göre farkl1lık gösterip göstermediğini belirlemeye yönelik oluşturulan hipotezler 
tek yönlü varyans analizi (ANOVA) kullanılarak test edilmiştir. Analiz sonuçları aşağıda değerlendirilmiştir.

Plansız satın alma davranışının yaşa göre farklılık gösterip göstermediğini belirlemeye yönelik tek yönlü varyans analizi (ANOVA) yapılmıştır. Ancak bu analiz öncesinde analizin temel varsayımı olan varyansların homojenliğinin sağlanması gerekmektedir. Varyansların homojen dağılıp dağılmadığını belirlemek için Levene testi yapılmıştır. Aşağıdaki Tablo 5'de Levene testi sonuçları görülmektedir.

Tablo 5. Levene Testi Sonuçlan

\begin{tabular}{lllll}
\hline & F & df1 & df2 & p \\
\hline Plansız Satın Alma Davranışı & 2,841 & 4 & 432 & 0,024 \\
\hline
\end{tabular}

Tablo 5'de görüldüğü üzere, $p$ değeri 0,024 olarak bulunmuştur. $p$ değerinin $0,05^{\prime}$ den küçük olması $(\mathrm{p}=0,024<0,05)$, varyansların homojen dağılmadığını göstermektedir. Tek yönlü varyans analizinin (ANOVA) temel varsayımı olan varyansların homojenliği sağlanmadığı durumlarda alternatif olarak Welch ve Brown-Forsythe testleri kullanılmaktadır. Dolayısıyla verilere önce Welch ve Brown-Forsythe testleri uygulanmıştır. Aşağıdaki Tablo 6'da, değişkenlere ilişkin betimsel istatistikler, Welch ve Brown-Forsythe testlerinin sonuçları ve Tamhane T2 testi sonucu ulaşılan gruplar arası farklılıklar gösterilmektedir.

Tablo 6'daki Welch ve Brown-Forsythe testi sonuçları incelendiğinde, $\mathrm{p}$ değerlerinin $0,05^{\prime}$ den küçük olduğu $(\mathrm{F}(\mathrm{W})=7,949$, $\mathrm{p}=0,000<0,05$; $\mathrm{F}(\mathrm{BF})=3,734, \mathrm{p}=0,006<0,05)$ görülmektedir. Buna göre, tüketicilerin plansız satın alma davranışı yaşa göre anlamlı bir farklılık göstermektedir. Farklılığın hangi gruplar arasında olduğunu belirlemek amaciyla varyansların homojen olmadığı durumlarda kullanılan çoklu karşılaştırma testlerinden Tamhane T2 testi uygulanmıştır. Tamhane T2 testi sonucunda, 20 ve altı yaş grubunda olan tüketicilerin plansız satın alma puanları $(3,146 \pm 1,021)$, 51 ve üzeri yaş grubunda olan tüketicilerin plansız satın alma puanlarından $(1,644 \pm 0,669)$ yüksek bulunmuştur. 21-30 yaş grubunda olan tüketicilerin plansız satın alma puanları (2,908 $\pm 1,145), 51$ ve üzeri yaş grubunda olan tüketicilerin plansız satın alma puanlarından $(1,644 \pm 0,669)$ yüksek bulunmuştur. $31-40$ yaş grubunda olan tüketicilerin plansız satın alma puanları $(3,003 \pm 1,171), 51$ ve üzeri yaş grubunda 
olan tüketicilerin plansız satın alma puanlarından $(1,644 \pm 0,669)$ yüksek bulunmuştur. 41-50 yaş grubunda olan tüketicilerin plansız satın alma puanları $(2,921 \pm 1,240)$, 51 ve üzeri yaş grubunda olan tüketicilerin plansız satın alma puanlarından $(1,644 \pm 0,669)$ yüksek bulunmuştur. Görüldüğü üzere, gruplar arası farklılık 51 ve üzeri yaş grubundan kaynaklanmaktadır. Dolayısıyla $\mathrm{H}_{3}$ hipotezi kabul edilmiştir.

Tablo 6. Betimsel İstatistikler / Welch ve Brown-Forsythe Testlerinin Sonuçlar

\begin{tabular}{|c|c|c|c|c|c|c|c|c|c|}
\hline & \multirow[b]{2}{*}{ Yaş } & \multirow[b]{2}{*}{$\mathbf{N}$} & \multirow[b]{2}{*}{$\overline{\mathrm{X}}$} & \multirow[b]{2}{*}{ ss. } & \multicolumn{2}{|c|}{$\mathbf{F}$} & \multicolumn{2}{|c|}{$\mathbf{P}$} & \multirow[b]{2}{*}{ Fark } \\
\hline & & & & & Welch & $\begin{array}{l}\text { Brown- } \\
\text { Forsythe }\end{array}$ & Welch & $\begin{array}{l}\text { Brown- } \\
\text { Forsythe }\end{array}$ & \\
\hline \multirow{6}{*}{$\begin{array}{l}\text { Plansız } \\
\text { Satın Alma } \\
\text { Davranışı }\end{array}$} & 20 ve altı & 15 & 3,146 & 1,021 & 7,949 & 3,734 & 0,000 & 0,006 & \multirow{5}{*}{$\begin{array}{l}1>5 \\
2>5 \\
3>5 \\
4>5\end{array}$} \\
\hline & $21-30$ & 228 & 2,908 & 1,145 & & & & & \\
\hline & $31-40$ & 134 & 3,003 & 1,171 & & & & & \\
\hline & $41-50$ & 51 & 2,921 & 1,240 & & & & & \\
\hline & 51 ve üzeri & 9 & 1,644 & 0,669 & & & & & \\
\hline & Toplam & 437 & 2,921 & 1,164 & & & & & \\
\hline
\end{tabular}

Plansız satın alma davranışının eğitim durumuna göre farklılık gösterip göstermediğini belirlemek için tek yönlü varyans analizi (ANOVA) yapılmıştır. Bu analiz öncesinde varyansların homojenliğini belirlemek amacıyla Levene testi yapılmıştır. Aşağıdaki Tablo 7'de Levene testi sonuçları görülmektedir.

Tablo 7. Levene Testi Sonuçları

\begin{tabular}{lllll}
\hline & F & df1 & df2 & p \\
\hline Plansız Satın Alma Davranışı & 2,027 & 4 & 432 & 0,090 \\
\hline
\end{tabular}

Tablo 7'de görüldüğü üzere, $p$ değeri 0,090 olarak bulunmuştur. $p$

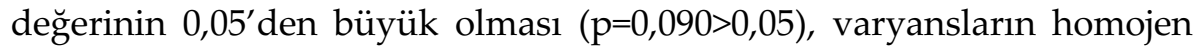
olduğunu göstermektedir. Varyansların homojenliği varsayımının sağlanmasının ardından yapılan tek yönlü varyans analizinin (ANOVA) sonuçları aşağıdaki Tablo 8'de görülmektedir.

Tablo 8. Eğitim Durumuna Göre Tek Yönlü Varyans Analizi (ANOVA) Sonuçlar

\begin{tabular}{llllll}
\hline & Kareler Top. & Df & Kareler Ort. & F & p \\
\hline Gruplar aras1 & 6,877 & 4 & 1,719 & 1,270 & 0,281 \\
Gruplar içi & 584,735 & 432 & 1,354 & & \\
\hline Toplam & $\mathbf{5 9 1 , 6 1 2}$ & $\mathbf{4 3 6}$ & & & \\
\hline
\end{tabular}


Tablo 8 incelendiğinde, $\mathrm{p}$ değerinin 0,05 'den büyük olduğu $(\mathrm{F}=1,270$, $\mathrm{p}=0,281>0,05)$ görülmektedir. Buna göre, tüketicilerin plansız satın alma davranışı eğitim durumuna göre anlamlı bir farklılık göstermemektedir. Dolayısıyla $\mathrm{H}_{4}$ hipotezi reddedilmiştir.

Plansız satın alma davranışının gelire göre farklılık gösterip göstermediğini belirlemek için tekrar tek yönlü varyans analizi (ANOVA) yapılmıştır. Bu analiz öncesinde varyansların homojenliğini belirlemek amacıyla Levene testi yapılmıştır. Aşağıdaki Tablo 9'da Levene testi sonuçları görülmektedir.

Tablo 9. Levene Testi Sonuçları

\begin{tabular}{lllll}
\hline & F & df1 & df2 & p \\
\hline Plansız Satın Alma Davranışı & 1,581 & 4 & 432 & 0,178 \\
\hline
\end{tabular}

Tablo 9'da görüldüğg̈ü üzere, $p$ değeri 0,178 olarak bulunmuştur. $p$ değerinin 0,05 'den büyük olması $(p=0,178>0,05)$, varyansların homojen olduğunu göstermektedir. Varyansların homojenliği varsayımının sağlanmasının ardından yapılan tek yönlü varyans analizinin (ANOVA) sonuçları aşağıdaki Tablo 10'da görülmektedir.

Tablo 10. Gelire Göre Tek Yönlü Varyans Analizi (ANOVA) Sonuçları

\begin{tabular}{llllll}
\hline & Kareler Top. & Df & Kareler Ort. & F & p \\
\hline Gruplar arası & 7,536 & 4 & 1,884 & 1,394 & 0,235 \\
Gruplar içi & 584,076 & 432 & 1,352 & & \\
\hline Toplam & $\mathbf{5 9 1 , 6 1 2}$ & $\mathbf{4 3 6}$ & & & \\
\hline
\end{tabular}

Tablo 10 incelendiğinde, $\mathrm{p}$ değerinin 0,05 'den büyük olduğu $(\mathrm{F}=1,394$, $\mathrm{p}=0,235>0,05)$ görülmektedir. Buna göre, tüketicilerin plansız satın alma davranışı gelire göre anlamlı bir farklılık göstermemektedir. Dolayısıyla $\mathrm{H}_{5}$ hipotezi reddedilmiştir.

Araştırma hipotezlerinin test edilmesinin ardından hipotezlerin kabul / red durumuna ilişkin özet aşağıdaki Tablo 11'de görülmektedir.

Tablo 11 incelendiğinde, tüketicilerin plansız satın alma davranışının cinsiyete ve yaşa göre farklılık gösterdiği görülmektedir. 
Tablo 11. Araştırma Hipotezlerinin Kabul / Red Durumu

\begin{tabular}{ll}
\hline Araştırma Hipotezleri & Sonuçlar \\
\hline H1: Tüketicilerin plansız satın alma davranışı cinsiyete göre anlamlı bir farklılık & Kabul \\
gösterir. & \\
$\begin{array}{l}\text { H2: Tüketicilerin plansız satın alma davranışı medeni duruma göre anlamlı bir } \\
\text { farklılık gösterir. }\end{array}$ & Red \\
$\begin{array}{l}\text { H3: Tüketicilerin plansız satın alma davranışı yaşa göre anlamlı bir farklılık göste- } \\
\text { rir. }\end{array}$ & Kabul \\
$\begin{array}{l}\text { H4: Tüketicilerin plansız satın alma davranışı eğitim durumuna göre anlamlı bir } \\
\text { farklılık gösterir. }\end{array}$ & Red \\
$\begin{array}{l}\text { H5: Tüketicilerin plansız satın alma davranışı gelire göre anlamlı bir farklılık } \\
\text { gösterir. }\end{array}$ & Red \\
\hline
\end{tabular}

\section{Sonuç ve Öneriler}

Bu çalışmada, tüketicilerin plansız satın alma davranışının demografik özelliklere göre farklılık gösterip göstermediği araştırılmıştır. Araştırma sonucunda, plansız satın alma davranışının tüketicilerin cinsiyetine ve yaş grubuna göre farklılık gösterdiği bulunmuştur. Araştırma sonucunda, cinsiyet açısından kadın tüketicilerin erkek tüketicilere göre daha fazla plansız satın alma yaptığı bulunmuştur. Konuyla ilgili literatür incelendiğinde, bir çok araştırmacının da (Ekeng vd., 2012; Gandhi vd., 2015; Harwani ve Kanade, 2017; Khan vd., 2016; Özgüven Tayfun, 2015; Sangalang vd., 2017) benzer sonuca ulaştığı görülmektedir. Dolayısıyla ilgili araştırmaların sonuçlarıyla bu çalışmada cinsiyete ilişkin elde edilen bulgular benzerlik göstermektedir. Ancak sadece Awan ve Abbas (2015), Öz ve Mucuk (2015) ve Özoğlu ve Bülbül (2017 tarafından yapılan araştırmalarda bu çalışmadan farklı olarak, erkek tüketicilerin kadın tüketicilere göre daha fazla plansız satın alma yaptığı sonucu bulunmuştur.

Araştırma sonucunda ulaşılan bir diğer bulgu, plansız satın alma davranışının tüketicilerin yaş grubuna göre farklılık göstermesidir. Araştırma sonucunda, 51 ve üzeri yaş grubunda olan tüketicilerin diğer tüketicilere göre daha az plansız satın alma yaptığ tür incelendiğinde, bu araştırma sonucunun Awan ve Abbas'ın (2015), 51-60 yaş arasındaki tüketicilerin plansız satın alma davranışını en az gösteren yaş grubu olduğu sonucuyla örtüştügü görülmektedir. Bu sonucun ortaya çıkmasında, 51 ve üzeri yaş grubunda olan tüketicilerin, 
daha alt yaş gruplarında olan tüketicilere göre alışverişi hazcı bir eylemden ziyade ihtiyaçlarını karşılamaya yönelik olarak gerçekleştirdikleri, harcama konusunda daha tasarruflu veya bilinçli davrandıkları ya da ruh halleri, duygusal durumlarına vb. bağlı olarak ortaya çıkan ve onları plansız satın almaya yöneltebilecek dürtüleri kontrol etme yeteneğine daha fazla sahip oldukları için en az plansız satın alma yapan grup olduğu genel değerlendirmesi yapılabilir. Ancak bu konuda daha kesin değerlendirmeler yapabilmek için plansız satın alma davranışının yaş açısından incelenirken duygusal, durumsal vb. faktörler de göz önüne alınarak daha detaylı bir şekilde araştırılması gerektiği düşünülmektedir.

Araştırma sonucunda ulaşılan diğer bulgular, tüketicilerin medeni durumu, eğitim durumu ve aylık gelirine göre plansız satın alma davranışının farklılık göstermediğidir. İlgili literatür incelendiğinde, bulunan araştırma sonucuyla benzer şekilde Özoğlu ve Bülbül (2017), Yadav ve Mishra (2017), Yang vd. (2011) gibi araştırmacıların da tüketicilerin medeni durumuna göre plansız satın alma davranışının farklılık göstermediği sonucuna ulaştığı görülmektedir. Ciunova-Shuleska (2012), Kılıç (2017) ve Yang vd. (2011), tüketicilerin eğitim durumuna göre plansız satın alma davranışının farklılık göstermediğini bulmuşlardır. Ghani ve Jan (2011), Khan vd. (2016), Kılıç (2017), Özgüven Tayfun (2015) ve Yang vd. (2011) de plansız satın alma davranışının tüketicilerin gelirine göre farklılık göstermediği sonucuna ulaşmışlardır. Görüldüğü üzere, ilgili çalışmaların sonuçları bu çalışmada elde edilen bulguları destekler niteliktedir.

Bu çalışmada kadın tüketicilerin erkek tüketicilere göre daha fazla plansız satın alma yaptığı bulgusuna ulaşılmasında, kadın tüketicilerin erkek tüketicilere göre alışverişte daha fazla zaman harcamaları, alışveriş yapmayı sevmeleri ve hazcı bir eylem olarak görmelerinin (Coley ve Burgess, 2003; Kruger ve Byker, 2009; Tifferet ve Herstein, 2012) etkili olabileceği düşünülmektedir. Ancak, gelecekteki araştırmalarda kadın tüketicilerin plansız satın alma davranışlarının ruh halleri, duygusal durumları, hazcı tüketim, cinsiyete yönelik ayırıcı kişilik özellikleri, mağaza içi faktörler gibi pek çok faktör göz önüne alınarak araştırılması bu konuda kesin bir değerlendirme yapmak açısından faydalı olabilecektir. 
İşletmelerin ve/veya pazarlamacıların erkek tüketicileri plansız satın almaya yöneltebilecek özel stratejiler geliştirmeleri gerektiği düşünülmektedir. Ancak, erkek tüketiciler alışverişi hazcı bir eylemden ziyade ihtiyaç duydukları ürünleri olabildiğince kısa zaman harcayarak satın alabilecekleri faydacı bir eylem ve/veya görev olarak gördükleri için (Dittmar, Long ve Meek, 2004; Banyte, Rutelione ve Jaruseviciute, 2015; Vijaya Lakshmi, Aparanjini Niharika ve Lahari, 2017) onları plansız satın almaya yöneltmek oldukça zordur. Dolayısıyla işletmelerin ve/veya pazarlamacıların erkek tüketicileri plansız satın almaya yöneltebilecek stratejiler geliştirirken erkeklerin kişilik özellikleri, alışverişte zaman harcamayı sevmemeleri, faydacı alışveriş eğiliminde olmaları gibi faktörleri dikkate almaları gerekmektedir. Bu bağlamda ürün kategorileri de önemlidir. Zira yapılan araştırmalar incelendiğinde, erkek tüketicilerin en fazla plansız satın alma yaptıkları ürünlerin müzik CDleri ve DVDler, bilgisayar oyunları, donanım ve yazılım ürünleri, elektronik ürünler gibi teknolojik ve eğlence ürünleri (Bezzina, 2011; Coley ve Burgess, 2003) ile gıda ve bakkaliye ürünleri (Khokhar, Ahmed, Rashid ve Qureshi, 2018) olduğu görülmektedir. Dolayısıyla, özellikle birden fazla ürün kategorisinin satışını yapan perakende mağazaları bu ürünleri mağazaların kolaylıkla görülebilecek yerlerine veya giriş bölümlerine yerleştirerek erkek tüketicilerin hızlı ve kolay şekilde bu ürünlere ulaşarak plansız satın alma yapmalarını sağlayabilirler. Ayrıca, elektronik ve teknolojik ürünlerin çalışır halde sergilemesi erkek tüketicilerin görme ve duyma duyularına, gıda ürünlerinin pişirilerek sunulması ise erkek tüketicilerin koklama ve tatma duyularına hitap ederek onları plansız satın almaya yöneltebilir.

İşletmeler, 51 ve üzeri yaş grubunda olan tüketicileri plansız satın almaya yöneltebilmek için satış elemanlarının bu özel tüketici grubunun yaşam tarzı, tüketim alışkanlıkları vb. konularda bilgi sahibi olmalarını sağlamalı, ikna ve satış taktikleri açısından satış elemanlarını eğitmelidir. Bu tüketicilerin, kişisel bakım, giyim, elektronik vb. ürünlerden ziyade ev tekstili ve gıda ürünlerini tercih ettikleri düşünülmektedir. Dolayısıyla bu ürünlere yönelik promosyon ve fiyat indirimleri yapılabilir. Ayrıca, çoğunluğunu emekli ve/veya çalışmayan tüketicilerin oluşturduğu bu gruba yönelik promosyon ve fiyat indirimleri için hafta içi günleri tercih edilebilir. 
İlgili literatürde konuyla ilgili bazı çalışmaların belirli bir ürün, ürün kategorisi ve/veya sektör seçilerek yapıldığı görülmektedir. İlgili çalışmalardan bazılarında, demografik özelliklere göre tüketicilerin plansız satın alma davranışının farklılık gösterip göstermediğini, Yang vd. (2011) kozmetik ürünleri açısından, Gandhi vd. (2015) içecek ürünleri açısından, Rana ve Tirthani (2012) ise hazır giyim ürünleri açısından araştırmışlardır. Bu çalışmada ise belirli bir ürün, ürün kategorisi ve/veya sektör seçilmemiştir. Gelecekteki çalışmaların belirli bir ürün, ürün kategorisi ve/veya sektör seçilerek yapılması faydalı olabilir. Zira belirli bir ürün, ürün kategorisi ve/veya sektör seçilerek yapılan çalışmaların, ilgili ürün ve/veya ürün kategorisini üreten ve/veya satışını yapan ve/veya ilgili sektörde faaliyet gösteren işletmelerin tüketicileri plansız satın almaya yönlendirmeye ilişkin geliştireceği stratejiler açısından fayda sağlayabileceği düşünülmektedir. Ayrıca, tüketicilerin demografik özellikleri açısından plansız satın alma davranışının, Özoğlu ve Bülbül'ün (2017) giyim ve teknoloji ürünlerine yönelik gerçekleştirdiği çalışmasında olduğu gibi birkaç ürün kategorisi seçilerek karşılaştırmalı olarak analiz edilmesi de önerilebilir. Zira karşılaştırmalı olarak yapılacak araştırmalar, birden fazla sektörde faaliyet gösteren işletmeler açısından yol gösterici nitelikte olabilir.

İnternetin gündelik hayatın bir parçası haline gelmesiyle birlikte, tüketiciler internet üzerinden de plansız satın alma yapmaya başlamışlardır. Dolayısıyla online plansız satın alma davranışına yönelik çalışmaların sayısı artmaya başlamıştır. İlgili çalışmaların online plansız satın alma davranışını etkileyen faktörler üzerine yoğunlaştığı, ancak tüketicilerin demografik özelliklerine göre online plansız satın alma davranışının farklılaşıp farklılaşmadığını belirlemeye yönelik çalışmaların sayısının oldukça kısıtlı (Akram vd., 2018; Sharma ve Kaur, 2015; Wang, 2015) olduğu görülmektedir. Dolayısıyla tüketicilerin demografik özellikleri açısından online plansız satın almayı araştıran çalışmaların artması önerilebilir. Bu durum özellikle internet ortamında satış yapan işletmeler açısından faydalı olacaktır.

Literatürde, tüketicilerin cinsiyeti kadar "bireylerin varoluşsal erkeksiliği ya da kadınsılığı" (Spence, 1984, s.83) olarak tanımlanan cinsiyet kimliği de önemlidir. Dolayısıyla, tüketicilerin cinsiyet kimliği açısından plansız satın alma davranışı farklılık gösterebilir. Bu nedenle, gelecekteki 
çalışmalarda plansız satın alma davranışı cinsiyet kimliği açısından da araştırılabilir. Bu konuda literatürde önemli bir boşluk bulunmaktadır.

Tüketicilerin plansız satın alma davranışının demografik özelliklere göre farklılık gösterip göstermediğini Türkiye'de araştıran çalışmalar (Kılıç, 2017; Öz ve Mucuk, 2015; Özgüven Tayfun, 2015; Özoğlu ve Bülbül, 2017) oldukça kısıtlıdır. Dolayısıyla Türkiye'de konuyla ilgili çalışma sayısının arttırılması ve bu çalışmaların farklı sektör uygulamaları, daha geniş örneklemler ve birkaç demografik özellik bir arada ele alınarak yapılması gerektiği düşülmektedir.

$\mathrm{Bu}$ çalışmanın verileri, Bursa ilinde yaşayan tüketicilerden elde edilmiştir. Araştırmanın farklı bir ilde, Türkiye genelinde ve/veya farklı bir ülkede yaşayan tüketicilerin yer aldığı bir örneklem grubu üzerinde yapılması halinde farklı sonuçlar elde edilebilecektir. Dolayısıyla gelecekte yapılacak çalışmaların kapsamının bu yönlerden de farklılaştırılması önerilebilir. 


\section{EXTENDED ABSTRACT}

\section{Research to Examine Differences in Consumers' Impulse Buying Behavior in terms of Demographic Characteristics \\ Gamze Akçay- Erkan Özdemir \\ Bursa Uludă̆ University}

In the literature, there are studies investigating whether consumers' impulse buying behavior differs according to demographic characteristics (Awan and Abbas, 2015; Ciunova-Shuleska, 2012; Gandhi et al. 2015; Rana and Tirthani, 2012; Yang et al. 2011). However, especially in Turkey, studies investigating consumers' impulse buying behavior on a large sample group in terms of all demographic characteristics such as gender, marital status, age, education status, and income are quite limited (Kılıç, 2017; Özoğlu and Bülbül, 2017). Therefore, this study aims to reveal whether consumers' impulse buying behavior differs according to gender, marital status, age, education status and income on a large sample. Therefore, it is thought that this study contributes to the literature.

In the study, convenience sampling was used as a sampling method and research data were collected from 437 consumers in Bursa by a faceto-face survey. The questionnaire used in the study consists of two parts. In the first part, there are five categorical questions to determine the demographic characteristics of the participants. In the next part, there are 5point Likert-type scale questions consisting of five items and developed by Weun, Jones, and Beatty (1997) to measure consumers' impulse buying behavior. The data were analyzed by reliability analysis, frequency analysis, t-test, and one-way ANOVA.

As a result of the analysis, the reliability of the scale (Cronbach's Alpha value) was found 0.912 . Then, the data related to the demographic characteristics of the participants were examined by frequency analysis. According to the results of the analysis, most of the participants were male $(57 \%)$ and $21-30$ age group (52.2\%) consumers. Married participants $(50.3 \%)$ were more than single $(49.7 \%)$. Most of the participants were 
university graduates (54\%), and more than half of participants $(59.5 \%)$ had a monthly income of between 2001 - 4000 Turkish Liras.

T-test was used to determine whether consumers' impulse buying behavior differed according to gender and marital status. As a result of the analysis, it was found that consumers' impulse buying behavior showed a significant difference according to gender; however, no significant difference according to marital status. According to this finding, female consumers exhibit more impulse buying behavior than male consumers. When the literature is examined, it is seen that many researchers (Ekeng et al., 2012; Gandhi et al., 2015; Harwani and Kanade, 2017; Khan et al., 2016; Özgüven Tayfun, 2015; Sangalang et al., 2017) reached similar results. Therefore, the findings of the related studies and gender findings in this study are similar. However, in the studies conducted by Awan and Abbas (2015), Öz and Mucuk (2015) and Özoğlu and Bülbül (2017), unlike this study, it was found that male consumers exhibited more impulse buying behavior than female consumers.

Finally, one-way ANOVA was used to determine whether consumers' impulse buying behavior differed according to age, education status, and income. As a result of the analysis, it was found that consumers' impulse buying behavior showed a significant difference according to age, however, no significant difference according to education status and income. According to this finding, consumers of 51 and overages exhibit less impulse buying behavior than other consumers. Similar to this finding, Awan and Abbas (2015) found that consumers between the ages of 51 and 60 exhibited less impulse buying behavior than other consumers.

As mentioned above, in this study, it was found that consumers' impulse buying behavior did not show a significant difference in terms of marital status, education status, and income. According to the literature review, Özoğlu and Bülbül (2017), Yadav and Mishra (2017), Yang et al. (2011) found that the consumers' impulse buying behavior did not differ according to marital status. Ciunova-Shuleska (2012), Kılıç (2017) and Yang et al. (2011) found that the consumers' impulse buying behavior did not differ according to the education status. Ghani and Jan (2011), Khan et al. (2016), Kılıç (2017), Özgüven Tayfun (2015) and Yang et al. (2011) concluded that the consumers' impulse buying behavior did not 
differ according to the income. As can be seen, the results of the related studies support the findings obtained in this study.

In Turkey, studies investigating the consumers' impulse buying behavior in terms of demographic characteristics is limited. Therefore, in the future, it is thought that these studies should be increased and these studies should be conducted on wider samples by selecting different sectors or product categories. Also, consumers' impulse buying behavior should be investigated in terms of different demographic characteristics as well as gender, marital status, age, education status, and income. In addition, gender identity, which expresses the existential masculinity or femininity of individuals (Spence, 1984: 83), is also important. Hence, it is thought to be useful to investigate impulse buying behavior in terms of consumers' gender identity. Finally, the data of this study was obtained from consumers living in Bursa. Different results can be obtained if the research is conducted on consumers living in different cities or countries.

\section{Kaynakça / References}

Akram, U., Hui, P., Khan, M. K., Yan, C. ve Akram, Z. (2018). Factors affecting online impulse buying: Evidence from Chinese social commerce environment. Sustainability, 10(2), 1-28.

Awan, A. G. ve Abbas, N. (2015). Impact of demographic factors on impulse buying behavior of consumers in Multan-Pakistan. European Journal of Business and Management, 7(22), 96-105.

Banyte, J., Rutelione, A. ve Jaruseviciute, A. (2015). Modelling of male shoppers behavior in shopping orientation context. Procedia-Social, and Behavioral Sciences, 213, 694-701.

Beatty, S. E. ve Ferrell, M. E. (1998). Impulse buying: Modeling its precursors. Journal of Retailing, 74(2), 169-191.

Bezzina, J. (2011). Gender differences in impulse buying behaviour. 28.03.2019 tarihindehttps://www.um.edu.mt/library/oar/handle/123456789/3289 adresinden erişilmiştir.

Ciunova-Shuleska, A. (2012). The impact of situational, demographic, and socioeconomic factors on impulse buying in the republic of Macedonia. Journal of East-West Business, 18(3), 208-230. 
Clover, V. T. (1950). Relative importance of impulse buying in retail stores. Journal of Marketing, 15(1), 66-70.

Coley, A. ve Burgess, B. (2003). Gender differences in cognitive and affective impulse buying. Journal of Fashion Marketing and Management, 7(3), 282-295.

Dittmar, H., Long, K. ve Meek, R. (2004). Buying on the internet: Gender differences in on-line and conventional buying motivations. Sex Roles, 50(5), 423-444.

Ekeng, A. B., Lifu, F. L ve Asinya, F. A. (2012). Effect of demographic characteristics on consumer impulse buying among consumers of Calabar Municipality, Cross River State. Academic Research International, 3(2), 568-574.

Gandhi, A., Vajpayee, A. ve Gautam, D. (2015). A study of impulse buying behavior and factors influencing it with reference to beverage products in retail stores. 15.04.2019 tarihinde https://www.sibm.edu/pdf/samvad8/impulse.pdf adresinden erişilmiştir.

Ghani, U. ve Jan, F. A. (2011). An exploratory study of the impulse buying behaviour of urban consumers in Peshawar. International Conference on Business and Economics, 1, 157-159.

Graa, A. ve Dani-Elkebir, M. (2012). Application of stimulus \& response model to impulse buying behavior of Algerian consumers. Serbian Journal of Management, 7(1), 53-64.

Gudonaviciene, R. ve Alijosiene S. (2015). Visual merchandising impact on impulse buying behaviour. Procedia - Social and Behavioral Sciences, 213, 635-640.

Hair, J. F., Black, W.C., Babin, B. J. ve Anderson, R. E. (2014). Multivariate data analysis. Pearson New International Edition, (7th ed.), Essex: Pearson.

Harwani, S. ve Kanade, S. R. (2017). Impact of demographic differences and other factors on impulse buying. International Journal of Management, $8(2), 58-67$.

Husnain, M., Rehman, B., Syed, F. ve Akhtar, M. W. (2019). Personal and instore factors influencing impulse buying behavior among generation Y consumers of small cities. Business Perspectives and Research, 7(1), 92-107. 
Khan, N., Hui, L. H., Chen, T. B. ve Hoe, H. Y. (2016). Impulse buying behaviour of generation $\mathrm{Y}$ in fashion retail. International Journal of Business and Management, 11(1), 144-151.

Khokhar, A., Ahmed, A., Rashid, K. ve Qureshi, J. A. (2018). Males as impulsive buyers: how do they get affected?, Journal of Organizational Behavior Research, 3(2), 173-188.

Kruger, D. ve Byker, D. (2009). Evolved foraging psychology underlies sex differences in shopping experiences and behaviors. Journal of Social, Evolutionary, and Cultural Psychology, 3(4), 315-27.

Kılıç, A. (2017). Plansız satın alma davranışlarının demografik özelliklere göre farklılıkları. Turkish Journal of Marketing, 2(3), 155-167.

Mohan, G., Sivakumaran, B. ve Sharma, P. (2013). Impact of store environment on impulse buying behavior. European Journal of Marketing, 47(10), 1711-1734.

Öz, M. ve Mucuk, S. (2015). Tüketici satın alma davranışı kapsamında hedonik (hazcı) tüketimin plansız alışveriş üzerine etkilerinin incelenmesi. Pazarlama Teorisi ve Uygulamalar Dergisi, 1(2), 37-60.

Özgüven Tayfun, N. (2015). Market alışverişlerinde plansız satın alma davranışında demografik farklılığ1 belirlemeye yönelik bir araştırma. Selçuk Üniversitesi Sosyal Bilimler Enstitüsü Dergisi, 34, 8794.

Özoğlu, B. ve Bülbül, H. (2017). İçgüdüsel satın alma ve demografik özellikler ile ilişkisi: Teknoloji ve giyim ürünlerinde karşılaştırmalı bir analiz. Süleyman Demirel Üniversitesi İktisadi ve İdari Bilimler Fakültesi Dergisi, 22(3), 769-783.

Rana, S. ve Tirthani, J. (2012). Effect of education, income, and gender on impulsive buying among Indian consumer an empirical study of readymade garment customers. Indian Journal of Applied Research, 1(12), 145-146.

Rasheed, A., Yaqup, R. M. S. ve Baig, F. J. (2017). Factors affecting impulse buying behaviors in shopping malls: evidence from Bahawalpur region, Pakistan. Journal of Marketing and Consumer Research, 39, 1-20.

Rook, D. W. (1987). The buying impulse. The Journal of Consumer Research, 14(2), 189-199.

Rook, D. W. ve Hoch, S. J. (1985). Consuming impulses. Advances in Consumer Research, 12, 23-27. 
Rook, D. W. ve Gardner, M. P. (1993). In the mood: impulse buying's affective antecedents. Research in Consumer Behavior, 6(7), 1-28.

Sangalang, R. A., Siochi, J. ve Plaza, M. (2017). Factors influencing consumers' impulse buying behavior in the fifth district of Cavite. DLSU Research Congress 2017, June, 1-6.

Sharma, K. C. ve Kaur, S. (2015). The impact of demographic factors on impulse buying behaviour of online and offline consumers. International Journal of Engineering Technology, Management and Applied Sciences, 3(9), 63-69.

Spence, J. T. (1984). Masculinity, femininity and gender-related traits: a conceptual analysis and critique of current research. Progress in Experimental Personality Research, 13, 1-97.

Stern, H. (1962). The significance of impulse buying today. Journal of Marketing, 26(2), 59- 62.

Tifferet, S. ve Herstein, R. (2012). Gender differences in brand commitment, impulse buying, and hedonic consumption. Journal of Product $\mathcal{E}$ Brand Management, 21(3), 176 -182.

Tinne, W. S. (2011). Factors affecting impulse buying behavior of consumers at superstores in Bangladesh. ASA University Review, 5(1), 209-220.

Torlak, Ö. ve Tiltay, M. (2010). Anlık satın alma ölçeklerinin Türk tüketicisi için uyarlanmasına yönelik bir deneme. 15. Ulusal Pazarlama Kongresi, İzmir, 406-422.

Türk, Z. (2018). Hedonik ve faydacı tüketim eğiliminin plansız satın alma davranışı üzerindeki etkisi: Bir araştırma. Uluslararası Toplum Araştırmaları Dergisi, 9(16), 854-878.

Vijaya Lakshmi, V., Aparanjini Niharika, D. ve Lahari, G. (2017). Impact of gender on consumer purchasing behaviour. Journal of Business and Management, 19(8), 33-36.

Virvilaite, R., Saladiene, V. ve Bagdonaite, R. (2009). Peculiarities of impulsive purchasing in the market of consumer goods. Engineering Economics, 2, 101-109.

Wang, H. (2015). Study of influencing factors on consumer online impulse buying. Management Science and Research, 4(2), 19-25.

Weun, S., Jones, M. A. ve Beatty, S. E. (1997). A parsimonious scale to measure impulse buying tendency. (W. M. Pride, and G.T. Hult, Eds.), AMA Educators's Proceedings: Enhancing Knowledge Development in Marketing, Chicago, American Marketing Association, 306-307. 
Yadav, S. K. ve Mishra, BD. (2017). Effect of psychographics and demographics on impulse buying behavior of retail consumers in Bilaspur. International Journal of Commerce and Management Research, 3(1), 18-23.

Yang, D., Huang, K. C. ve Feng, X. (2011). A Study of the factors that affect the impulsive cosmetics buying of female consumers in Kaohsiung, International Journal of Business and Social Science, 2(24), 275-282.

$\mathrm{Yu}, \mathrm{C}$. ve Bastin, M. (2010). Hedonic shopping value and impulse buying behavior in transitional economies: A symbiosis in the mainland China marketplace. Journal of Brand Management, 18(2), 105-114.

\section{Kaynakça Bilgisi / Citation Information}

Akçay, G. ve Özdemir, E. (2019). Demografik özellikler açısından tüketicilerin plansız satın alma davranış farklılıklarını incelemeye yönelik bir araştırma. OPUS-Uluslararası Toplum Araştırmaları Dergisi, 14(20), 817-846. DOI: 10.26466/opus.596873 